\title{
The Need for Active and Involved Citizens
}

Nicos SHIAFKALIS

Centre of the International Theatre Institute, Cyprus

Two are the main issues on which I will focus my paper; one, that democracy was created in ancient Greece and two, that ancient Greek tragedy was also created there, at the same time.It is generally accepted that dialogue is the basis of democracy ( people's power).

Democracy appeared in ancient Greece the moment that Thespis broke out of the chorus and started a dialogue. From then on democracy developed in parallel with the development of ancient Greek drama.

In most of the ancient Greek tragedies and comedies, if we look carefully, we shall find seeds of the democratic ideal. I will refer to some of them at a later stage. For the moment I focus on the issue of dialogue, which gave birth to democracy, and which is the subject of my story.

Etymologically dialogue means 'through logos', persuasion through speech, through rational arguments and not imposing one's opinion on the other by decree, blackmail, threat, violence or otherwise.

Nowadays in most countries the citizens elect their governments and they have very little involvement in its general policy. But can we claim that our present day democracy is based on dialogue?

Can we claim that our modern democracy is similar to its great ancestor? Most, if not all modern democracies are democracies by representatives and many others are only by name democracies or republics, but they are in fact authoritarian regimes.

Political scientists describe ancient Greek democracy as a 'direct' democracy and modern democracy as a 'representative' democracy.

Coming down to basics we can say that the difference between the two is that the ancient Athenian democratic citizen would not trust 


\section{The Need For Active And Involved Citizens}

representatives and had a direct say in public affairs, which were discussed regularly in the 'agora'.

Every Athenian citizen had the right, but also the obligation to participate directly in the decision making process about public affairs, that is to say politics. So, the 'polis' was not just a congregation of houses and other buildings, 'but men made the polis' as Thucidides informs us. The affairs of the polis were everybody's affair. And if a citizen was not directly involved in the public affairs, was shamefaced.

Of course the transition from the city state to the nation state makes it really impossible to have all decisions taken by the whole population. The maximum population of a city state in Attica would not exceed the number of twenty or thirty thousands. Nowadays the populations of nation states come to a few millions. So we compromise by having elections for the House of Representatives every four years. We elect representatives or leaders which are recallable every four years, judged by the electoral body. But is this solution the best solution for the democratic ideal?

During the period of four years between elections, there may arise serious issues that concern the whole population, whether they have voted the government in power or not.

The European Union countries supported Bush in the Iraq war against the will of the majority of the citizens.

Bush decided the war against Iraq, although he was elected as president with about $60 \%$ abstentions in the elections. Whether his decision was right or wrong, it was definitely not democratic.

During parliamentary elections in many countries we hear a lot of protests by the poorer candidates against the advantage that richer candidates had in advertising their candidateship on TV and the other mass media, which could brainwash anybody. And this is really another crucial issue in our discussions, regarding democracy: access to unbiased information. 


\section{Nicos SHIAFKALIS}

In Athens of the 5th century B.C, all citizens were informed through the performances of drama about all public issues and they discussed them openly the next day in the agora.

Public opinion in modern democratic countries is shaped according to the interests of the few, who are controlling the mass media. High technology is at the service of financial and cultural globalization. And just as the industrial revolution accumulated the world's wealth and power in the hands of the very few, the technological revolution will accumulate power in the hands of the still fewer, as a matter of fact in the hands of the media tycoons. And this danger is also hovering over the whole world.

In ancient Greece public opinion was shaped by the theatre performances, which were attended by all the citizens, who voted directly about all important issues of foreign or internal affairs.

In the year 2002 the Cyprus Centre of the International Theatre Institute dedicated the Seventh International Symposium on Ancient Greek Drama to the theme of the democratic ideal.

Allow me here to quote short a passage from David Lovell's paper on the subject:

".............The real question is not whether drama was linked to politics, but how. It seems that tragedy was not explicitly an attempt to indoctrinate citizens, though it raised issues, and even questioned assumptions, about the polis. It wasn't (directly) civic training. It wasn't (directly) the ideology of democracy. I want to emphasize here two important points about Greek theatre. First, it raised public issues, though it was not didactic, or propagandistic. It was in an important sense another venue where public concerns could be raised. Second, Greek theatre highlighted the role of the gods in human affairs. It was emphasized, in particular, that happiness consisted in harmony between the divine and human spheres. This was the translation into drama of a debate occurring in philosophy - a debate which continues to this day - about the relations between law and morality, or between the human law (nomos) of the polis and the divine law (logos) 


\section{The Need For Active And Involved Citizens}

David Lovell, in the same paper says:

"................... Participation in public life included the theatre. The theatre played out moral dilemmas and problems that citizens might confront in their public life. Theatre was not a diversion from life; it was an important part of life. This understanding of life as a public conversation sustained democracy in many city-states over a couple of hundred years................"

Coming back to tragedy, we are convinced that all three tragedians in many cases touch on the issue of democracy, by means of persuasion rather than by means of didacticism.

Starting with Aeschylus, we find mention of democracy almost in all his extant tragedies. In the PERSIANS, the answer of the Chorus to the question of Atossa, as to who is the king of Athens, that they, (the Athenians) "...... are slaves to no man nor subjects to any ruler...", is a statement of a fact regarding the democratic rule of Athens.

In the SUPPLIANTS, Pelasgus, the king of the Argives tells Danaus that he cannot give asylum to his daughters without the consent of his demos.

In SEVEN AGAINST THEBES, Eteocles, although a monarch in sole command, feels the need to address his people of his decision to defend the city.

In PROMETHEUS, Power and Violence (Kratos and Via) are used as the iron arm of Zeus to impose his authoritarian wish to destroy the human race. The mere opposition against the wish of almighty Zeus is in itself a sign of democratic view.

Last and not least in ORESTEIA, the declaration of Athena in EUMENIDES for the establishment of Arios Pagos (a Supreme Court) is another hint for the need of a democratic ideal in the Athenian politics.

Sophocles and Euripides likewise refer indirectly and directly to the Athenian politics. In his SUPPLIANTS, Euripides has Theseus saying to the herald from Thebes "....you are mistaken looking for a master here, the city is free and it is not governed by a single man." In his MEDEA, he has 


\section{Nicos SHIAFKALIS}

Athens giving asylum to the banished from Corinth alien heroine. In the PHOENICIAN WOMEN, Iocasta talks to her sons about equal rights.

But apart from the direct references, Euripides brings on stage issues of authoritarian rule, so that his contemporary spectators could compare it to the Athenian liberal and democratic system. Such examples are the atrocities of the Greek Army in the TROJIAN WOMEN, the banishment of Medea from Corinth, the arbitrary Agamemnon's decision for the war against Troy and the brutal sacrifice of his Iphigenia and many more, which escape from my mind right now.

Sophocles likewise, although considered by many scholars as a conservative, in many of his tragedies he refers directly and indirectly to political issues favoring democracy. The chorus in OEDIPUS REX claims that "...hubris breeds tyranny ..", in his ANTIGONE, Creon behaves as a dictator and his son Haemon tells him that he can only apply his kind of rule on a desert island. In his ELECTRA, she disapproves of her mother and Aegistus usurping power In PHILOCTETES, Neoptolemos, representing the new generation, opposes the conservative views of Odysseus and the Atreids. And who knows what were in the other ninetythree tragedies which were not saved.

Coming back to the point of our discussion, - democracy in ancient Greek drama - there is no doubt that all three tragedians (and Aristophanes in his own way), supported the democratic ideal of the Athenian state in their plays and walked hand in hand to the glory of the 'golden age'.

The important point I wish to underline is the fact that the politicians realizing the tremendous effect that theatre had on the spectators, not only did they not censor them, but on the contrary they supported them, providing them with the means to play a leading role in the society, shaping public opinion. The polis was involved in the theatre performances, paying for the production expenses and more over for the cost of the tickets of the poor, who couldn't afford it. By this way the whole population was involved in public affairs and the arguments discussed in the agora. 
The Need For Active And Involved Citizens

The word of the dramatists was much more convincing than that of the philosophers and the demagogues because it had a direct effect on the spectator, as something that really happens and not theoretical.. The spectator went through the same tragic experience as the tragic hero.

Now to conclude, the question arises as to what is the lesson that we, in contemporary terms, can learn from the function of democracy in ancient Greece, through the theatre. Surely even if we could reconstruct a performance of ancient Greek drama exactly like it was performed at the time, we could not reconstruct the audience and its context. But we can learn that democracy needs citizens who are active, interested and involved in public issues, participating in all decision making fora and playwrights who can bring on the stage issues of public concern. 